\title{
An Overview of Experimental Models on Ischemic Heart Diseases
}

\author{
Demet Sinem Guden ${ }^{1}$ (-), Ahmet Ozer Sehirli² \\ ${ }^{1}$ Mersin University, Faculty of Pharmacy, Department of Pharmacology \\ ${ }^{2}$ Near East University, Faculty of Dentistry, Department of Pharmacology \\ Correspondence Author: Demet Sinem Guden \\ E-mail: dsinem.guden@gmail.com \\ Received: 30.07.2019 Accepted: 26.08.2019
}

\begin{abstract}
Objective: Heart failure is commonly defined as a heart dysfunction associated with pulmonary alveolar blood flow and consequent inability to ensure adequate blood supply to the tissues or to meet the body's metabolic demand. Currently, there is a considerable lack of experimental uniformity for ischemic heart models as well as types of ischemia. Therefore, our objective is to summarize frequently applied methods that are designed to evaluate ischemic heart diseases. Asystematic search was conducted to review experimental models according to keywords. In general, iatrogenic and transgenic cardiomyopathy models were used in the literature. These models were designed to generate global and regional ischemia. Our review is conducted to evaluate experimental models with the intent of improving the modelling of ischemic heart diseases. Poor modelling can contribute to high mortality and morbidity rates in cardiology. Given the wide range of models available, the future animal models of ischemic heart failure will potentially provide more efficient and reliable preventative measures in the fight against complex cardiovascular diseases.
\end{abstract}

Keywords: ischemia/reperfusion, heart failure, cardiomyopathy

\section{INTRODUCTION}

Ischemic heart disease is one of the most common causes of heart failure. Ventricular dilatation, hypertrophy, biochemical changes, and edema develop as a result of weakening of the pump capacity due to myocardial damage. In studies conducted to date, two different ischemic models are noted. The first is generally associated with cardiac arrest, usually occurring during iatrogenic cardiopulmonary by-pass surgery or global ischemia. Global ischemia is characterized by increases in coronary flow occuring despite ventricular fibrillation and the other is localized ischemia which is associated with a localized myocardial infarction. There are significant differences in biochemical and electrophysical characteristics between these two types of ischemia (1-4).

\section{METHODS}

This study was conducted from 2011 and August 2019 in Pubmed database. We searched reviews and orginal articles conducted in ischemic heart diseases to improve the modelling of global or regional ischemia. We categorized studies by using keywords including "animal models of heart failure" in combination "myocardial ischemia reperfusion injury". We summarized the outcomes of well-documented protocols about global and regional ischemia.

\section{RESULTS AND DISCUSSION}

\subsection{Global Ischemia}

Surgically induced global ischemia in humans is often used in combination with cardioplegia formulations designed to minimize myocardial damage. As a result, ischemia is a short relief, however, when the cross-clamp in the aorta is removed and the myocardium is reperfused, it is easily recycled. The protective agents may be injected before or during the induction of ischemia. When global ischemia develops due to ventricular fibrillation or cardiac arrest, any protective agent is less likely to be used before the onset of damage. There is a prominent lack of experimental procedure showing the onset time of the ischemia or reperfusion prior to the various parameters of interest being monitored (5-7). However, global ischemia/reperfusion (I/R) reproduces the effects of $\mathrm{I} / \mathrm{R}$ on the heart when the heart is arrested/restarted during cardiac surgery (8). The Langendorff and the isolated working heart models are the predominant experimental models of acute global or regional myocardial I/R (8).

In order to study the effects of global ischemia/reperfusion $(I / R)$ isolated rat hearts have been widely used in several studies. In one study, working isolated hearts were exposed to global I/R for 20 minutes before reperfusion, while in another study non-working perfused isolated rat hearts were induced ischemia for 25 minutes and then reperfused for 30 minutes 
(9-11). Ikizler et al. (2003) using crystalloid cardioplegia, rendered rat hearts that were perfused in isolated Langerdorf tissue and inoperative for 120 minutes, were then reperfused for 30 minutes to investigate the protective effect of trimetazidine, an agent that was reported to be protective against ischemia in the cellular stage (12). Wishmeyer et al. (2003) injected glutamine (alanine-glutamine dipeptide) to Sprague-Dawley rats 18 hours prior to removing the heart tissue. After the perfusion of the hearts, 15 minutes were allowed for global ischemia induction and another 60 minutes were allowed for the induction of the reperfusion (13). In a study, isolated Sprague-Dawley rat hearts were perfused with a modified Krebs buffer solution for $15 \mathrm{~min}$ to stabilize the cardiac functions and then subjected to $30 \mathrm{~min}$ of global ischemia, followed by $45 \mathrm{~min}$ of reperfusion (14). In the streptozocin-induced diabetes model, the hearts of rats were found to be equivalent to each other and were first exposed to ischemia for 5 minutes at low flow and 25 minutes without flow then reperfused for 30 minutes in order to study the diabetes treatment drug, glibechlamidin's, effect on long term I/R damage (15). In another study using isolated heart samples exposed to 30 minutes of ischemia and 30 minutes of reperfusion, a similar diabetic model was used to find the role of protein kinase $C$ translocation during $I / R$ injury (16). Jungi et. al. (2018) studied the effect of the inotropic $\mathrm{Ca}^{2+}$ - sensor protein (S100A1) overexpressing hearts. They used isolated rat hearts perfused in working mode and subjected them to $28 \mathrm{~min}$ ischemia $\left(37^{\circ} \mathrm{C}\right.$ ) followed by 60 min reperfusion.

The effects of resveratrol, a pure antioxidant found in peas and red wine, was evaluated in isolated rat hearts, which were perfused in Langerdorff tissue, exposed to global ischemia for 60 minutes and reperfusion for 60 minutes (18). Dyck et al. applied three different protocols to isolated rat hearts; 60 minutes of aerobic perfusion, 30 minutes of aerobic perfusion and baseline which is $35 \%$ reduced flow for 30 minutes of perfusion, followed by 60 minutes of reperfusion to study the effects of malonyl coenzyme, a decarboxylase inhibition (19). In isolated rat hearts studied at a flow rate of $0.4 \mathrm{ml} /$ min (low speed), the effects of both neuronal ATP-sensitive $K$ + channels and extraneuronal monoamine delivery systems were evaluated (20). Wistar rats were subjected to warm global $\mathrm{I} / \mathrm{R}$ using a pressure-controlled Langendorff system and performed $0,15,30$ and 40 min of ischemia with $30 \mathrm{~min}$ of reperfusion, respectively. This study seeks to determine the role of ischemia periods on respiratory chain functions and $\mathrm{Ca}^{2+}$-handling of cardiac subsarcolemmal mitochondria (21).

In the isolated hearts of Japanese white rabbits, the development of continuous myocardial energy metabolisms for 45 minutes during normothermic global ischemia was found to be cardioprotective (22). Isolated isovolumic rabbit hearts were exposed to global ischemia for 15 minutes and reperfusion for 30 minutes in hypercontrusion studies which are phenomena that occur in the myocardium at the beginning of reperfusion (23). Another study used isolated hearts from adult New Zealand rabbit. The hearts were placed into cold $\left(4^{\circ} \mathrm{C}\right) \mathrm{Krebs}-\mathrm{Henseleit}$ solution following to a Langendorff apparatus and perfused with the same solution to analyze various electrogram parameters which were recorded simultaneously by a touch-less method using the orthogonal lead system. The experimental protocol consisted of 25 min stabilization, $5 \mathrm{~min}$ the rotation of the heart, global ischemia and reperfusion (each $10 \mathrm{~min}$ long) (24).

Pigs were often used in myocardial I/R studies during cardiopulmonary by-passes to make it more similar to global ischemia. The protocols established for ischemia and reperfusion have changed with different studies. Castella et al. exposed the pigs to normothermic global ischemia for 30 minutes during infusion of buffered or unbuffered cardioplegic solution enriched with glutamate and aspartate followed by aortic clamping for 30 minutes (25). In order to mimic the ischemic time, ranging from 40 to 90 minutes, a team with surgical experience was employed in their laboratory (26-28). In order to form hypoxia, newborn pigs were exposed to $8 \%$ oxygen ventilation in nitrogen using hypoxic myocardial modeling. Myocardial damage in these animals was evaluated according to the cardiac troponin I concentration in the blood (29).

In a study of type 2 diabetic rats, the phosphodiesterase- 5 inhibitor tadalafil was found to be protective against myocardial I/R damage and attenuated oxidative stress. Adult diabetic male mice and control rats were used in this study. Diabetic rats were randomly treated with dimethylsulfoxide (0.2\% i.p.) or tadalafil (1 mg / kg tadalafil i.p. dissolved in $10 \%$ DMSO) for 28 days. At the end of 28 days, the mice were killed and their blood collected to look at the biochemical parameters, and heart tissues were isolated to gather more information about the damage. Langendorff generated global $\mathrm{I} / \mathrm{R}$ damage in mice with this method. Under anesthesia, the hearts of mice were rapidly removed from the thorax and perfused with heparin after being placed in a small plate containing ice. The aortic patency of the heart was quickly connected by a 20 gauge non-sharp needle using Langendorff perfusion system. After the bonding process, the heart was perfused under continuous $50 \mathrm{~mm}-\mathrm{Hg}$ pressure in a KrebsHenseleit solution. The solution was comprised of $118 \mathrm{mM}$ $\mathrm{NaCl}, 24 \mathrm{mM} \mathrm{NaHCO}$, $2.5 \mathrm{mM} \mathrm{CaCl} 2,4.7 \mathrm{mM} \mathrm{KCl}, 1.2 \mathrm{mM}$ KH2PO4, 1.2 mM MgSO4, $11 \mathrm{mM}$ glucose and $0.5 \mathrm{mM}$ EDTA. A gas mixture of $95 \% \mathrm{O} 2-5 \% \mathrm{CO} 2$ (pH $7.34-7.49)$ was passed through the perfusion solution continuously in a hot/ cold bath. Heart temperature was monitored continuously and throughout the experiment a temperature of $37^{\circ} \mathrm{C}$ was maintained. After a 30 minutes of stabilization period, the heart was exposed to global ischemia by clamping the aortic cannula-dependent perfusion tube. Reperfusion was initiated by opening the aortic cannula and continued for 60 minutes. After the end of reperfusion, the heart was removed from the Langendorff apparatus, weighed and frozen at $-20^{\circ} \mathrm{C}$. The frozen heart was then divided into 7-8 vertical pieces of equal length and was incubated at room temperature with $10 \mathrm{mM}$ trifenyltetraazolium chloride (triphenyltetrazolium chloride; TTC). After the TTC solution, it was incubated in $10 \%$ formaldehyde and the infarct size and risk area were 
combined for 4 to 6 hours before they were measured by computer. The risky region was calculated according to cavities in total ventricular area and ventricular area. Infarct size was calculated according to the percentage of risky regions $(30,31)$. In other methods of $I / R$ injury of the isolated working perfused rat heart was subjected to constant left atrium pressure and aortic pressure. Then the control hearts were subjected to $35-\mathrm{min}$ normothermic global ischemia followed by 5-min Langendorff perfusion with subsequent 30-min reperfusion according to a modified method of Neely. The experimental group of hearts was perfused for 5 min with Krebs-Henseleit buffer in Langendorff after global ischemia (32).

\subsection{Regional Ischemia}

During infarction or regional ischemia, the functioning of the pump must be maintained. Great efforts have been made and are still underway in cardiovascular research to find physical and pharmacological interventions to reduce the size of the infarct, maintain the normal contractile ability of living tissue, accelerate healing of damaged tissue, and stimulate growth and / or regeneration of living tissue. Experimental models to achieve targets should be similar to the situation observed in the clinic, if possible. In many experiments, it was assumed that there was an area of regional ischemia, including very heavy ischemic tissues with tissue damage as well as tissue damage in the affected area to assess tissue damage and / or decrease in size of the infarction. It is assumed that moderately damaged tissue forms a boundary region around the heavily damaged core. This border region is the target for many interventions. There are also many experimental models such as acute infarction models in which this border region does not exist. There is a definite but irregular transition from normal to ischemic myocardium (33). In males, there are differences, such as the absence of a moderately damaged area in illnesses with coronary artery disease, and acute infarction models applied to healthy animals may be problematic.

Ligation of diagonal or marginal branches of the left anterior descending coronary artery provides insight into the systemic influences on the heart after myocardial $\mathrm{l} / \mathrm{R}$ or $\mathrm{MI}$ in different animal species $(8,34)$. In this procedure, anesthetized animals were subjected to left thoracotomy to expose LAD, and then a suture or occlusion device was used to either temporarily occlude or permanently ligate the LAD or a branch of the $\operatorname{LAD}(8,35)$. "Closed chest" methods were also used to study transient or chronic LAD occlusion $(8,36)$. Until recently, dogs were widely used to produce coronary artery disease and myocardial I/R injury as an animal model, but this seemed suspicious because the coronary vessel system of pigs was more similar to that of men (37). The right coronary artery and the left main coronary artery (LAD) in pigs are similar in males and less similar to the left circumflex artery (4). In dogs, approximately $40 \%$ of the myocardium is located in the right circumflex and LAD and approximately $15 \%$ in the right coronary artery, respectively. In addition, branching models in the coronary artery, pupilla muscles and nodal conduction are more similar in males and pigs $(38,39)$. In dogs, there are 3 or 4 relatively large subepicardial anastomoses assisting the coronary system. Pigs have a slightly smaller endocardial anastomosis between the right and left coronary arteries. Although the condition in humans appears similar to both pig and dog, it is more similar to the coronary system of pigs (4). The evidence is the progressive stenosis in the coronary arteries for complementary stimulation (40).

The blood flow in the major coronary arteries was cut acutely in pigs, sheep, and rabbits, and the anastomoses were insufficient to prevent necrosis and/or fatal ventricular arrhythmia. Following acute ligation, the survival rates of dogs, mice, and rats were found to be equal $(4,41)$. The location of the specific coronary artery is difficult to determine precisely, because the coronary vasculature in rats and mice can be from the epicardial to the subepicardial. Since a practical point of view has been developed, acute ligation of the coronary arteries in these species is performed in the general location of the coronary artery and by suturing with a tight connection to the myocardium containing the entire area with the vessel (41).

Although the cross branches of baboons are collected in a third main coronary, the coronary blood flow is very similar to that of humans. As a result of coroner ligation, marked lesions and changes in tissue were observed in baboons. There are no clear boundaries in this area (40). The occurrence of myocardial necrosis and infarct-like lesions were occasionally recorded in baboons without atherosclerotic coronary artery disease. These lesions are thought to be endocrine/ neurogenic rooted due to stress and severe catecholamine release (40).

A number of detailed devices have been discovered to create a coronary occlusion. These tools include a chrome-plated silicon rubber plunger that is bent to fit the pressure plate with a non-rusting steel pressure plate. In order to improve the mobility of the coronary artery in the heart, there is a need for a 12-inch 17-gauge non-rusting steel pipe system with a thin wall in the form of a hook. The end part of the pipe system is covered with silver to fit the set of assembly mounted (polymethylmethacrylate) at the solid side. The plunger is plated with silver for the second time in order to remove the chrome-plated plunger from the thin-walled pipe system and to maintain the constant pressure of the springloaded metal part micrometer axis. This tool is designed to create linear pressure in the cross-sectional area. It also has a direct drive arm for fully clogged vessels inside the instrument when it is not manually operated. It has been reported that the instrument is impeccable, easy to wear and usable, and produces specific stenosis when used simultaneously. Another technique is the use of 00 nylon sutures which rotate around a very small ring, and each has two plastic blocks at the end. The two plastic blocks are mounted on the co-metal bars, one of which can be removed and the turning diameter can be changed. The distance between blocks can be fully measured with the Vernier caliper. The relationship between 
this distance and the radius of rotation is linear. A band of 2-3 $\mathrm{mm}$ width can be passed around the arteries; then a steep tube is taken to the machine's micrometer. Repeated reproducible stenosis has been reported with this technique (4).

Ameroid constructors have also been used in many different animal models to produce graded stenosis. Placement of it requires a thoracotomy and dissection of a coronary artery. This artery was occluded in 3-6 weeks with collateral circulation $(42,43)$. The expansion agent in this material is hydrophilic ameroid casein. The material usually contains a solid capsule, which makes the vessels dilate by damaging the surrounding vessels as the material moves inward. Experience is required for the equipment. If $30 \%$ or more contraction occurs after the first 48 hours after administration, it becomes difficult to perform basal measurements at the perioperative after operation. The degree of stenosis formed cannot be adjusted and cannot be predicted. Almost all kinds of materials used on the outer surface of a vein cause hardening of the arteries, formation of moderate hypertrophy and also some reactions such as stenosis. In this technique, the degree of stenosis cannot be adjusted and it is unpredictable (41).

The most useful tool for creating acute vascular congestion is the tool discovered by Khouri and Greggin (1967) which is a version of inflatable clamps (44). Later, a hydraulic stopper was designed by In Vivo Metric Systems, (Healdsburg, CA). This tool is very useful when it is used in the direction of current flow depending on the transducer, so the congestion can be adjusted and measured.

Another technique is that coiling/gelfoam placement into the LAD in pigs. This method has no need for a thoracotomy for the placement of a suture around a diagonal branch. For reducing the suture complications like inflammation and development of collateral circulation, percutaneous transcatheter occlusion of coronary arteries has been facilitated by the development of platinum coils (Tornado Embolization Coils, Cook Group Inc, Bloomington, IN) (34).

Cryoinjury models (new model of myocardial infarction) are yielding promising results for the evaluation of left ventricular (LV) geometry, function with echocardiography, and assessment of electrophysiological remodeling or arrhythmia risk in mice, rats, and rabbits. A liquid nitrogen probe was applied for 20 seconds 15 times on the left ventricular wall $(34,35,45)$.

Very different coronary ligation techniques were used in dogs. Ischemic preconditioning was established by two-stage ligation at a distance of $2 \mathrm{~cm}$ from the center of the LAD coronary artery (4). Elzinga and Skinner found a U-shaped clamp that fits around the vessels to form clogs in the coronary artery and clamped the ends with the screw (46). This model is still an acute ligation model. Similar results can be obtained by wrapping a flow breaker slowly around the vein (4). Lekx et al. performed a decrease in LAD current by using a Doppler-flow inducer in dogs and by squeezing it with a bond until the desired reduction in flow was achieved
(47). Stenosis was provided within 3-10 weeks. In this model, perfusion capacity was measured by adenosis infusion and was found to decrease significantly.

As mentioned earlier, ischemia and reperfusion times vary considerably in each experimental protocol, and at the same time, these values are rarely rational. For example, dogs were exposed to LAD occlusion for 15 minutes at a time that was followed by reperfusion for 60 minutes (48). In another study, 60 minutes of LAD obstruction was subjected to 3 hours of reperfusion and in a study, the left circumflex coronary arteries of the dogs were blocked for 10 minutes and their hearts were reperfused for 24 hours $(49,50)$.

In order to clog the LAD for 45 minutes in pigs, clamps were used and then allowed for reperfusion for 6 hours (51). Following the acute ligation of proximal LAD, the use of a stent in the left ventricle as a coronary shunt provided adequate blood flow to the epicardium but failed to provide adequate blood flow to the endocardium (52). In another study with pigs, the clamps were placed on the left side of the left circumflex artery and epicardial radio-opaque markers were used. After surgical interventions, the animals recovered were sedated and placed in the basal area and then clamped to form a coronary occlusion. Refractory ventricular fibrillation was detected in 6 pigs with 45 minutes of coronary occlusion and these results were confirmed by experiments. Postmyocardial infarction was studied on living animals for 10 days (53). Permanent ischemia was created in another group of pigs for 2-3 weeks in the left circumflex artery (54). An ameroid constrictor was applied to the left circumflex of 94 pig (55). The non-occlusive coronary stenosis model in the pigs was formed by inflating the angioplasty balloon into the proximal LAD (56). Models related to clinical conditions in pigs were created by continuously eroding the epicardial LAD endothelium with the balloon and with a $50 \% \mathrm{Fe}_{2} \mathrm{Cl}_{3}$ solution (57-59). The solution was diffused into the wall of the vessel that damaged the endothelium and triggered the thrombus (59).

In small pigs, an infusion catheter was placed between the second and third cross branches of the LAD. Firstly, 1 polystyrene microspheres, followed by an increase in STsegment elevation in the ECG showing ischemia symptoms were infused with increasing doses of microspheres (60). Controlled LAD flow was reduced to about $20 \%$ and dobutamine was injected to increase heart rate and contractility to induce ischemia (19).

Sheep were used in the experiments to generate the left circumflex coronary artery and the LAD ligation (61-63). In rabbits, 30-minute ischemia was reperfused for 170 minutes and ischemia for 30 minutes, reperfusion for 120 minutes, and later in order to precondition 5 minutes of ischemia and 10 minutes of reperfusion was performed to create local infacts $(64,65)$. Thoracotomy was performed on the rabbits which were cooled to $-70^{\circ} \mathrm{C}$ using circulating nitric oxide in a $1.2 \mathrm{~cm}$ thick cryoprobe under anesthesia. After reaching the temperature, an anterolateral left ventricular wall was inserted into the epicardial area for 3 minutes 
and a transmural cryosurgical lesion of approximately 1.5 $\mathrm{cm}$ thickness was detected. The thorax was closed and the animals were expected to recover for 2 weeks before they were used in experiments to perform bone marrow transplantation or intracardiac transplantation (66).

LAD is attached in rats by thoracotomy. The rats were expected to heal and these animals were used in the experimental protocol to be performed after 3 and 4 weeks $(67,68)$. In a later study, reperfusion was applied to the left ventricular main artery of the rats for 25 minutes followed by 3 hours reperfusion and the size of the infarct was evaluated (49). In order to investigate the protective effects of synthetic xanthine derivatives on myocardial damage, rats were allowed to reperfusion for 120 minutes and to coronary ligation for 30 minutes (69).

Attempts have been made on rats to model a clinical condition leading to regional ischemia followed by ventricular fibrillation (global ischemia). Ventricular fibrillation was induced 4 weeks after the first coronary arteries of the rats were narrowed and the myocardial function of the animals was evaluated at the end of the experiment (70). In another study, the hearts taken 4 weeks after coronary ligation were subjected global ischemia for 25 minutes within the Langerdoff samples and 3 hours reperfusion afterward (71). Isolated perfused rat hearts were used to study the effect of I / R injury on apoptosis and infarct size. The hearts were ensured to receive damage to global ischemia, repeated three times, for 35 minutes each until the congestion in coronary arteries occurred followed by 120 minutes of reperfusion (72).

Mice are used with increasing frequency to investigate the changes in gene expression associated with heart failure $(4,73)$. Specific genes are replaced or mutated to show the changes in gene expression associated with heart failure because of the ability to use specific knockout or knockin transgenic models in mice $(35,73,74)$. Additionally, one of the most widely used methods is the occlusion of the left anterior descending coronary artery and then reperfusion of the artery (35). On the other hand, it was thought that heart failure resulting from patients with comorbid diseases including hypertension/hyperlipidemia/obesity/diabetes (73). In combining, these models with existing surgical techniques to create myocardial infarction models in mice, it was often necessary to suture to the site of LAD and distal to the atrioventricular junction. This technique is used to prevent the inhibition of proinflammatory cytokines by pioglitazone treatment in streptozotocin-induced diabetic mice, assessing the effects of angiotensin II receptor blockade, to prevent the cardiac rupture, to compare the effects of targeted deletion of p53 by using mice containing gene ${ }^{+/-}$p53 and

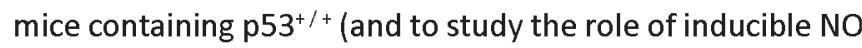
synthase by using iNOS ${ }^{-1-}$ (75-78). Thakkar et al. used mouse models to investigate the effect of diet-induced obesity on inflammation and healing following myocardial I/R (79). After 1 hour of LAD restriction, they provided blood flow back and tested the animals 1,3 , and 7 days after reperfusion. In order to find the role of Rho-kinase and Rho A in I / R injury, male CD1 mice were exposed to coronary obstruction for 30 minutes and reperfusion for 24 hours (80). The effect of isoflurane-induced myocardial protection was studied after 30 minutes of coronary occlusion in rats and reperfusion for 2 hours or 2 weeks (81). TNF- $\alpha^{-/-}$rats were used to find the role of TNF- $\alpha \%$ after the reperfusion on the 3,7,14 and 28 days of the experiment (82).

Guinea pigs are considered as the best animal model to study atherosclerosis induced $\mathrm{MI}$, because of their similarities to humans. Recently, Dasagrandhi et. al. (2018) investigated myocardial damage in male guinea pigs exposed to l/R injury. In this study, after the anesthetization of guinea pigs, left thoracotomy was performed by making a small incision into the $4^{\text {th }}$ and $5^{\text {th }}$ intercostal space through the ribs. The LAD was ligated using 5.0 catgut sutures. At the end of the $30 \mathrm{~min}$ of ischemia, the ligature was removed for $24 \mathrm{~h}$ and 7 days reperfusion periods and thoracotomy site was sutured. They suggested that a high-fat diet followed by $\mathrm{I} / \mathrm{R}$ injury proved to be an efficient model in the pathophysiology of myocardial I/R injury (83).

Surgical clipping of the coronary artery method has been further modified. In this method, a left coronary artery is repeatedly subject to the several short-term ischemia and reperfusion period and then permanently occluded to study ischemic preconditioning of the heart (35). Experimental protocols also exist with ischemic postconditioning which reduces the size of the infarction. For example, several intermittent short-term periods of coronary occlusion (30 s) at the beginning of reperfusion followed by prolonged occlusion have been studied in different animal species over the course of the experiment (74)

Van den Bos et al. used 2-3 mm cryoprobe to create a transmural, cone-shaped infarcts and after coronary ligation, he often found apical aneurysms of various sizes. In the 4 weeks following the injury, changes occurred as a $3 \mathrm{~mm}$ shortness of cryoinfarction's LV infarction shortness, a decrease in contractility, and progressing LV model (84).

\section{CONCLUSION}

Our review is conducted to evaluate experimental models to improve modeling of the ischemic heart diseases that can cause high mortality and morbidity rates in cardiology clinics while noting significant differences found in regional and global ischemia models in terms of biochemical and electrophysical characteristics.

\section{REFERENCES}

[1] Lombardi F, Casalone C, Della Bella P, Malfatto G, Pagani M, Malliani A. Global versus regional myocardial ischaemia: differences in cardiovascular and sympathetic responses in cats. Cardiovasc Res 1984; 18(1):14-23.

[2] Schaper J. Structural characteristics in regional versus global ischemia. Adv Myocardiol 1980; 2:311-314. 
[3] Kadayıfcı A. UTS Dahiliye. 4th ed. Ankara: Atlas Kitapclık Tic. Ltd. Sti; 2005.

[4] Gross DR. Animal Models in Cardiovascular Research. 2nd Revised ed. Boston: Kluwer Academic; 1994.

[5] Wolkart G, Kaber G, Kojda G, Brunner F. Role of endogenous hydrogen peroxide in cardiovascular ischaemia/reperfusion function. Studies in mouse hearts with catalase-overexpression in the vascular endothelium. Pharmacol Res 2006; 54:50-56.

[6] Gonon AT, Bulhak A, Broijersen A, Pernow J. Cardioprotective effect of an endothelin receptor antagonist during ischaemia/ reperfusion in the severely atherosclerotic mouse heart. $\mathrm{Br} J$ Pharmacol 2005; 144:860-866.

[7] Ashton KJ, Willems L, Holmgren K, Ferreira L, Headrick JP. Age-associated shifts in cardiac gene transcription and transcriptional responses to ischemic stress. Exp Gerontol 2006; 41:189-204.

[8] Abarbanell AM, Herrmann JL, Weil BR, Wang Y, Tan J, Moberly SP, Fiege JW, Meldrum DR. Animal models of myocardial and vascular injury. J Surg Res 2010; 162(2):239-49.

[9] du Toit EF, Rossouw E, Salie R, Opie LH, Lochner A. Effect of sildenafil on reperfusion function, infarct size, and cyclic nucleotide levels in the isolated rat heart model. Cardiovasc Drugs Ther 2005; 19:23-31.

[10] Lochner A, Genade S, Hattingh S, Marais E, Huisamen B, Moolman JA. Comparison between ischaemic and anisomycininduced preconditioning: Role of p38 MAPK. Cardiovasc Drugs Ther 2003; 17:217-230.

[11] Khudairi T, Khaw BA. Preservation of ischemic myocardial function and integrity with targeted cytoskeleton-specific immunoliposomes. J Am Coll Cardiol 2004; 43:1683-1689.

[12] Ikizler M, Dernek S, Sevin B, Kural T. Trimetazidine improves recovery during reperfusion in isolated rat hearts after prolonged ischemia. Anadolu Kardiyol Derg 2003; 3:303-308.

[13] Wischmeyer PE, Jayakar D, Williams U, Singleton KD, Riehm J, Bacha EA, Jeevanandam V, Christians U, Serkova N. Single dose of glutamine enhances myocardial tissue metabolism, glutathione content, and improves myocardial function after ischemia reperfusion injury. J Parenter Enteral Nutr 2003; 27(6):396-403.

[14] Yu Q, Li X, Cao X. Cardioprotective effects of phenylethanoid glycoside-rich extract from Cistanche deserticola in ischemiareperfusion induced myocardial infarction in rats. Ann Vasc Surg 2016; 34:234-242.

[15] Takahashi N, Ooie T, Saikawa T, Iwao T, Yoshimatsu $H$, Sakata T. Long-term treatment with glibenclamide increases susceptibility of streptozotocin-induced diabetic rat heart to reperfusioninduced ventricular tachycardia. Exp Biol Med (Maywood) 2003; 228:1234-1238.

[16] Ooie T, Takahashi N, Nawata T, Arikawa M, Yamanaka K, Kajimoto M, Shinohara T, Shigematsu S, Hara M, Yoshimatsu $\mathrm{H}$, Saikawa T. Ischemia-induced translocation of protein kinase C-epsilon mediates cardioprotection in the streptozotocininduced diabetic rat. Circ J 2003; 67:955-961.

[17] Jungi S, Fu X, Segiser A, Busch M, Most P, Fiedler M, Carrel T, Tevaearai Stahel H, Longnus SL, Most H. Enhanced cardiac S100A1 expression improves recovery from global ischemiareperfusion injury. J Cardiovasc Trans| Res 2018; 11(3):236245.

[18] Dernek S, Ikizler M, Erkasap N, Ergun B, Koken T, Yilmaz K, Sevin B, Kaygisiz Z, Kural T. Cardioprotection with resveratro pretreatment: Improved beneficial effects over standard treatment in rat hearts after global ischemia. Scand Cardiovasc J 2004; 38:245-254.

[19] Dyck JR, Cheng JF, Stanley WC, Barr R, Chandler MP, Brown S, Wallace D, Arrhenius T, Harmon C, Yang G, Nadzan AM, Lopaschuk GD. Malonyl coenzyme a decarboxylase inhibition protects the ischemic heart by inhibiting fatty acid oxidation and stimulating glucose oxidation. Circ Res 2004; 94:78-84.

[20] Burgdorf C, Dendorfer A, Kurz T, Schömig E, Stölting I, Schütte $F$, Richardt $G$. Role of neuronal KATP channels and extra neuronal monoamine transporter on norepinephrine overflow in a model of myocardial low flow ischemia. J Pharmacol Exp Ther 2004; 309:42-48.

[21] Leistner M, Sommer S, Kanofsky P, Leyh R, Sommer SP. Ischemia time impacts on respiratory chain functions and $\mathrm{Ca}^{2+}$ handling of cardiac subsarcolemmal mitochondria subjected to ischemia reperfusion injury. J Cardiothorac Surg 2019; 14(1):92.

[22] Kawabata H, Ishikawa K. Cardioprotection with pioglitazone is abolished by nitric oxidesynthase inhibitor in ischemic rabbit hearts - comparison of the effects of pioglitazone and metformin. Diabetes Metab Res Rev 2003; 19:299-305.

[23] Gonzalez GE, Mangas F, Chauvin AD, Monroy S, Donato M, Morales C, Gelpi RJ. Diastolic behavior during postischemic hypercontraction phase in rabbit stunned myocardium. Medicina (B. Aires) 2003; 63:403-409.

[24] Ronzhina M, Olejnickova V, Stracina T, Novakova M, Janousek O, Hejc J, Kolarova J, Hlavacova M, Paulova H. Effect of increased left ventricle mass on ischemia assessment in electrocardiographic signals: rabbit isolated heart study. BMC Cardiovasc Disord 2017; 17(1):216.

[25] Castella M, Buckberg GD, Saleh S, Tan Z, Ignarro LJ. A new role for cardioplegic buffering: Should acidosis or calcium accumulation be counteracted to salvage jeopardized hearts? J Thorac Cardiovasc Surg 2003; 126:1442-1448.

[26] Gross DR, Dewanjee MK, Zhai P, Lanzo S, Wu SM. Successful prosthetic mitral valve implantation in pigs. ASAIO J 1997; 43:382-386.

[27] Gross DR, Salley RK, Maley RH, Arden WA, Nammalwar P. Effects of internal mammary artery pedicle coronary artery bypass grafting on aortic valve leaflet positioning. J Heart Valve Dis 1995; 4:313-320.

[28] Sparks DL, Gross DR, Hunsaker JC. Neuropathology of mitral valve prolapse in man and cardiopulmonary bypass (CPB) surgery in adolescent Yorkshire pigs. Neurobiol Aging 2000; 21: 363-372.

[29] Borke WB, Munkeby BH, Morkrid L, Thaulow E, Saugstad OD. Resuscitation with $100 \% \mathrm{O}(2)$ does not protect the myocardium in hypoxic newborn piglets. Arch Dis Child Fetal Neonatal Ed 2004; 89:156-160.

[30] Koka S, Das A, Salloum FN, Kukreja RC. Phosphodiesterase-5 inhibitor tadalafil attenuates oxidative stress and protects against myocardial ischemia/reperfusion injury in type 2 diabetic mice. Free Radic Biol Med 2013; 60: 80-88.

[31] Qiang Y, Zhili G, Xiaofeng L, Qing O, Cheng He, Burnstock G, Yuan $H$, Xiang $Z$. Block of $P 2 X 7$ receptors could partly reverse the delayed neuronal death in area CA1 of the hippocampus after transient global cerebral ischemia. Purinergic Signal 2013; 9(4):663-675.

[32] Palkeeva M, Studneva I, Molokoedov A, Serebryakova L, Veselova O, Ovchinnikov M, Sidorova M, Pisarenko O. Galanin/ 
GalR1-3 system: A promising therapeutic target for myocardia ischemia/reperfusion injury. Biomed Pharmacother 2019; 109:1556-1562.

[33] Hearse DJ. Models and problems in the study of myocardia ischemia and tissue protection. Eur Heart J 1983; 4:43-48.

[34] Monnet E, Chachques JC. Animal models of heart failure: what is new? Ann Thorac Surg 2005; 79(4):1445-1453.

[35] Zaragoza C, Gomez-Guerrero C, Martin-Ventura JL, BlancoColio L, Lavin B, Mallavia B, Tarin C, Mas S, Ortiz A, Egido J. Animal models of cardiovascular diseases. J Biomed Biotechno 2011; 2011:497841.

[36] Kim SC, Boehm O, Meyer R, Hoeft A, Knüfermann P, Baumgarten $G$. A murine closed-chest model of myocardial ischemia and reperfusion. J Vis Exp 2012; (65):e3896.

[37] Verdouw PD, Wolffenbuttel BH, van der Giessen WJ. Domestic pigs in the study of myocardial ischemia. Eur Heart J 1983; 4 61-67.

[38] Eckstein RW. Coronary interarterial anastomoses in young pigs and mongrel dogs. Circ Res 1954; 2:460-465.

[39] Brooks H, Al-Sadir J, Schwartz J, Rich B, Harper P, Resnekov L. Biventricular dynamics during quantitated anterosepta infarction in the porcine heart. Am J Cardiol 1975; 36:765-775.

[40] Opie LH, Bruyneel KJ, Lubbe WF. What has the baboon to offer as a model of experimental ischemia? Eur Heart J 1983; 4:5560.

[41] Gross DR. Animal Models in Cardiovascular Research. 3nd Revised ed. USA: Springer; 2009

[42] Hartman JC, Kampine JP, Schmeling WT, Warltier DC. Actions of isoflurane on myocardial perfusion in chronically instrumented dogs with poor, moderate, or well-developed coronary collaterals. J Cardiothorac Anesth 1990; 4:715-725.

[43] Hirano A, Fujita J, Kanazawa H, Kawaguchi S, Handa N, Yamada Y, Okuda S, Hishikawa S, Teratani T, Kunita S, Tohyama S, Seki T , Tabei R, Nakajima K, Kishino Y, Okada M, Okamoto K, Shimizu $\mathrm{H}$, Kobayashi E, Fukuda K. Cryoinjury-induced acute myocardia infarction model and ameroid constrictor-induced ischemic heart disease model in adult micro-mini pigs for preclinical studies. Trans Med Comms 2017; 2:1.

[44] Khouri EM, Gregg DE. An inflatable cuff for zero determination in blood flow studies. J Appl Physiol 1967; 23:395-397.

[45] Lindsey ML, Bolli R, Canty JM Jr, Du XJ, Frangogiannis NG, Frantz S, Gourdie RG, Holmes JW, Jones SP, Kloner RA, Lefer DJ, Liao R, Murphy E, Ping P, Przyklenk K, Recchia FA, Schwartz Longacre L, Ripplinger CM, Van Eyk JE, Heusch G. Guidelines for experimental models of myocardial ischemia and infarction. Am J Physiol Heart Circ Physiol 2018; 314:812-838.

[46] Elzinga WE, Skinner DB. Hemodynamic characteristics of critical stenosis in canine coronary arteries. J Thorac Cardiovasc Surg 1975; 69:217-222.

[47] Lekx KS, Prato FS, Sykes J, Wisenberg G. The partition coefficient of Gd-DTPA reflects maintained tissue viability in a canine model of chronic significant coronary stenosis. J Cardiovasc Magn Reson 2004; 6:33-42.

[48] Morillas P, Hernandez A, Pallares V, Pallarés V, Bertomeu V Roldán FJ, Capdevilla C, Azorín I, Aguilar A, Portolés M, Cosín J. Usefulness of trimetazidine in ischemia-reperfusion lesion experimental study in myocardial stunning model. Arch Cardio Mex 2004; 74:262-270.

[49] Lubbers NL, Campbell TJ, Polakowski JS, Bulaj G, Layer RT, Moore J, Gross GJ, Cox BF. Postischemic administration of CGX-1051, a peptide from cone snail venom, reduces infarct size in both rat and dog models of myocardial ischemia and reperfusion. J Cardiovasc Pharmacol 2005; 46:141-146.

[50] Nikolaidis LA, Doverspike A, Hentosz T, Zourelias L, Shen YT, Elahi D, Shannon RP. Glucagon-like peptide-1 limits myocardial stunning following brief coronary occlusion and reperfusion in conscious canines. J Pharmacol Exp Ther 2005; 312:303-308.

[51] Khalil PN, Neuhof C, Huss R, Pollhammer M, Khalil MN, Neuhof $\mathrm{H}$, Fritz H, Siebeck M. Calpain inhibition reduces infarct size and improves dünya çapında hemodynamics and left ventricular contractility in a porcine myocardial ischemia/reperfusion model. Eur J Pharmacol 2005; 528:124-131.

[52] Engbers HM, de Zeeuw S, Visser T, Cramer MJ, Grundeman PF. Myocardial blood supply by left ventricle-to-coronary artery channel: An old idea revisited. Int J Cardiol 2006; 106:145-151.

[53] Apple KA, Yarbrough WM, Mukherjee R, Deschamps AM, Escobar PG, Mingoia JT, Sample JA, Hendrick JW, Dowdy KB, McLean JE, Stroud RE, O'Neill TP, Spinale FG. Selective targeting of matrix metalloproteinase inhibition in postinfarction myocardial remodeling. J Cardiovasc Pharmacol 2006; 47:228-235.

[54] Duncker DJ, Haitsma DB, Liem DA, Verdouw PD, Merkus D. Exercise unmasks autonomic dysfunction in swine with a recent myocardial infarction. Cardiovasc Res 2005; 65:889896.

[55] Radke PW, Heinl-Green A, Frass OM, Post MJ, Sato K, Geddes DM, Alton EW. Evaluation of the porcine ameroid constrictor model of myocardial ischemia for therapeutic angiogenesis studies. Endothelium 2006; 13:25-33.

[56] Yip G, Khandheria B, Belohlavek M, Pislaru C, Seward J, Bailey K, Tajik AJ, Pellikka P, Abraham T. Strain echocardiography tracks dobutamineinduced decrease in regional myocardial perfusion in nonocclusive coronary stenosis. J AmColl Cardiol 2004; 44:1664-1671.

[57] Saitoh S, Muto M, Osugi T, Aikawa K, Matsumoto K, Onog F, Maehara K, Ishibashi T, Maruyama Y. Repeated epicardial coronary artery endothelial injuries lead to a global spontaneous coronary artery spasm. Coron Artery Dis 2004; 15:137-145.

[58] Thompson CA, Reddy VK, Srinivasan A, Houser S, Hayase M, Davila A, Pomerantsev E, Vacanti JP, Gold HK. Left ventricular functional recovery with percutaneous, transvascular direct myocardial delivery of bone marrow-derived cells. J Heart Lung Transplant 2005; 24:1385-1392.

[59] Segers $P$, Tchana-Sato V, Leather HA, Lambermont B, Ghuysen A, Dogne JM, Benoit P, Morimont P, Wouters PF, Verdonck P, Kolh $P$. Determinants of left ventricular preload-adjusted maximal power. Am J Physiol Heart Circ Physiol 2003; 284:2295-2301.

[60] Zhang QY, Ge JB, Chen JZ, Zhu JH, Zhang LH, Lau CP, Tse HF. Mast cell contributes to cardiomyocyte apoptosis after coronary microembolization. J Histochem Cytochem 2006; 54:515 - 523

[61] Ryan LP, Jackson BM, Parish LM, Plappert TJ, St John-Sutton MG, Gorman JH, Gorman RC. Regional and global patterns of annular remodeling in ischemic mitral regurgitation. Ann Thorac Surg 2007; 84:553-559.

[62] Pilla JJ, Blom AS, Brockman DJ, Ferrari VA, Yuan Q, Acker MA. Passive ventricular constraint to improve left ventricular function and mechanics in an ovine model of heart failure secondary to acute myocardial infarction. J Thorac Cardiovasc Surg 2003; 126:1467-1476 
[63] Blom AS, Pilla JJ, Gorman RC III, Gorman JH, Mukherjee R, Spinale FG, Acker MA. Infarct size reduction and attenuation of global çapında left ventricular remodeling with the CorCap cardiac support device following acute myocardial infarction in sheep. Heart Fail Rev 2005; 10 (2):125-139.

[64] Tracey WR, Magee WP, Oleynek JJ, Hill RJ, Smith AH, Flynn DM, Knight DR. Novel N6-substituted adenosine 5-N-methyluronamides with high selectivity for human adenosine $A 3$ receptors reduce ischemic myocardial injury. Am J Physiol Heart Circ Physiol 2003; 285:2780-2787.

[65] Flynn DM, Smith AH, Treadway JL, Levy CB, Soeller WC, Boettner WA, Wisniecki P, Plowchalk DR, Gernhardt SS, Tracey WR, Knight DR. The sulfonylurea glipizide does not inhibit ischemic preconditioning in anesthetized rabbits. Cardiovasc Drugs Ther 2005; 19:337-346.

[66] Thompson RB, van den Bos EJ, Davis BH, Morimoto $\mathrm{Y}$, Craig D, Sutton BS, Glower DD, Taylor DA. Intracardiac transplantation of a mixed population of bone marrow cells improves both regional systolic contractility and diastolic relaxation. J Heart Lung Transplant 2005; 24:205-214.

[67] Woo YJ, Grand TJ, Berry MF, Atluri P, Moise MA, Hsu VM, Cohen J, Fisher O, Burdick J, Taylor M, Zentko S, Liao G, Smith M, Kolakowski S, Jayasankar V, Gardner TJ, Sweeney HL. Stromal cell-derived factor and granulocyte-monocyte colonystimulating factor form a combined neovasculogenic therapy for ischemic cardiomyopathy. J Thorac Cardiovasc Surg 2005; 130:321-329.

[68] Sehirli AO, Koyun D, Tetik Ş, Özsavcı D, Yiğiner Ö, Çetinel Ş, Tok $\mathrm{OE}$. Melatonin protects against ischemic heart failure in rats. $J$ Pineal Res 2013; 148-158.

[69] Dai Z, Jiang DJ, Hu GY, Du YH, Yu J, Hu CP, Luo D, Li YJ. 3,4,5,6-tetrahydroxyxanthone protects against myocardialischemia-reperfusion injury in rats. Cardiovasc Drugs Ther 2004; 18:279-288.

[70] Fang X, Tang W, Sun S, Huang L, Chang YT, Huang Z, Wei $\mathrm{MH}$. Cardiopulmonary resuscitation in a rat model of chronic myocardial ischemia. J Appl Physiol 2006; 101:1091-1096.

[71] Miki T, Miura T, Yano T, Takahashi A, Sakamoto J, Tanno M, Kobayashi H, Ikeda Y, Nishihara M, Naitoh K, Ohori K, Shimamoto K. Alteration in erythropoietin-induced cardioprotective signaling by post infarct ventricular remodeling. J Pharmacol Exp Ther 2006; 317:68-75

[72] Moolman JA, Hartley S, Van Wyk J, Marais E, Lochner A. Inhibition of myocardial apoptosis by ischaemic and betaadrenergic preconditioning is dependent on p38 MAPK. Cardiovasc Drugs Ther 2006; 20:13-25.

[73] Breckenridge R. Heart failure and mouse models. Dis Mode Mech 2010; 3(3-4):138-143.
[74] Chorroa FJ, Such-Belenguera L, López-Merino V. Animal models of cardiovascular disease. Rev Esp Cardiol 2009; 62(1):69-84.

[75] Shiomi T, Tsutsui $H$, Hayashidani $S$, Suematsu N, Ikeuchi M, Wen J, Ishibashi M, Kubota T, Egashira K, Takeshita A. Pioglitazone, a peroxisome proliferator-activated receptorgamma agonist, attenuates left ventricular remodeling and failure after experimental myocardial infarction. Circulation 2002; 106:3126-3132.

[76] Matsusaka H, Kinugawa S, Ide T, Matsushima S, Shiomi T, Kubota T, Sunagawa K, Tsutsui H. Angiotensin II type 1 receptor blocker attenuates exacerbated left ventricular remodeling and failure in diabetes-associated myocardial infarction. $J$ Cardiovasc Pharmacol 2006; 48:95-102.

[77] Matsusaka H, Ide T, Matsushima S, Ikeuchi M, Kubota T, Sunagawa K, Tsutsui H. Targeted deletion of p53 prevents cardiac rupture after myocardial infarction in mice. Cardiovasc Res 2006; 70:457-465.

[78] Liu YH, Carretero OA, Cingolani $O H$, Liao TD, Sun $Y, X u J, ~ L i$ LY, Pagano PJ, Yang JJ, Yang XP. Role of inducible nitric oxide synthase in cardiac function and remodeling in mice with heart failure due to myocardial infarction. Am J Physiol Heart Circ Physiol 2005; 289:2616-2623.

[79] Thakker GD, Frangogiannis NG, Bujak M, Zymek P, Gaubatz JW, Reddy AK, Taffet G, Michael LH, Entman ML, Ballantyne $\mathrm{CM}$. Effects of diet-induced obesity on inflammation and remodeling after myocardial infarction. Am J Physiol Heart Circ Physiol 2006; 291:2504-2514.

[80] Bao W, Hu E, Tao L, Boyce R, Mirabile R, Thudium DT, Ma XL, Willette RN, Yue TL. Inhibition of Rho-kinase protects the heart against ischemia/reperfusion injury. Cardiovasc Res 2004; 61:548-558.

[81] Tsutsumi YM, Patel HH, Lai NC, Takahashi T, Head BP, Roth DM. Isoflurane produces sustained cardiac protection after ischemia-reperfusion injury in mice. Anesthesiology 2006; 104:495-502.

[82] Sun M, Dawood F, Wen WH, Chen M, Dixon I, Kirshenbaum LA, Liu PP. Excessive tumor necrosis factor activation after infarction contributes to susceptibility of myocardial rupture and left ventricular dysfunction. Circulation 2004; 110:32213228.

[83] Dasagrandhi D, R ASK, Muthuswamy A, Lennox AM, Jayavelu T, Devanathan V, Kesavan Swaminathan J. Ischemia/reperfusion injury in male guinea pigs: An efficient model to investigate myocardial damage in cardiovascular complications. Biomed Pharmacother 2018; 99:469-479.

[84] van den Bos EJ, Mees BM, de Waard MC, de Crom R, Duncker DJ. A novel model of cryoinjuryinducedmyocardial infarction in the mouse: A comparison with coronary artery ligation Am J Physiol Heart Circ Physiol 2005; 289:1291-1300. 